\title{
ANALYTICAL COMPARATIVE STUDY OF EFFICIENCIES AMONG MONO-CRYSTALLINE, POLY -CRYSTALLINE AND THIN FILM (CdTe, CIGS) SOLAR CELL USING FILL FACTOR CALCULATION METHOD
}

\author{
Ruhan Mahmud Shams ${ }^{1}$, Md. Sharafat Hossain ${ }^{2}$ \\ ${ }^{I}$ Dept. of Electrical \& Electronic Engineering, Dhaka University of Engineering \& Technology, Bangladesh \\ ${ }^{2}$ Dept. of Electrical \& Electronic Engineering, Dhaka University of Engineering \& Technology, Bangladesh
}

\begin{abstract}
This paper describes the effective utilization of solar power through photovoltaic cell in an urban area in Bangladesh. Using solar power in solar panel as an alternative power source, the main limitation is which one should have the better performances. Most widely used solar Cells are Mono-crystalline, Poly-crystalline, Thin film (especially CdTe, CIGS). In this paper we are focusing on the efficiency level of different types of solar cell using fill factor calculation (FFC) method. If we use Solar PV array in a combined power system then Fill Factor $(F F)$ would play a vital role. In this (Indo-Pak Sub continent) region Solar PV doesn't capitalized as power generation in a conventional system. But if we look at the present scenario of power generation then we found scarcity of fossil fuels (Coal, Gas, Natural Gas, and Diesel) cause an alarming situation of electricity. The area of field study that we select for this aspect is Jhenaidah an urban area in Bangladesh located at $23^{\circ} 33^{\prime}$ north east latitude and $89^{\circ} 10^{\prime}$ East longitude.
\end{abstract}

Keywords: Solar PV, Thin Film, Fill Factor, Renewable Energy.

\section{INTRODUCTION}

Solar energy is an essential input for sustainable improvement of the society. There is a vast amount of potential regarding solar energy which it can provide quality power supply to remote areas. The abundant energy available in nature can be reformed to electricity in a sustainable way to prolong living standards of the people without access to the electricity grid. Solar energy is one of the purest energy which can be converted to electrical energy. Combining two or more renewable energies (such as Bio-Diesel and Solar PV) as a combined power system makes more feasible and reliable power system than conventional power system. Such combined power system gives the higher efficiency level based on their operating characteristics than that of single power source system. For choosing one of the solar cells among mono, poly crystalline and thin film (CdTe, CIGS) we have to focus on their efficiencies and efficiency depends on their fill factor (FF). Fill factor of a solar cell is the ratio of the open circuit voltage and short circuit current of maximum obtained power of the product. This paper elaborates the fill factor method. FF method is the way to find the best efficient solar cell. Result of this method is mono-crystalline which efficiency level is around $21 \%$ [1].

\subsection{Overview of Solar Energy in Bangladesh}

Bangladesh a very small country of South Asia region situated on the Bay of Bengal located at 2307' North latitude and 90035' East longitude. Existing power generation scenario of Bangladesh solar energy is only 5\% of their total generation. By 2020 Government of Bangladesh has set up a goal to provide electricity to all and make sure the price per unit must be in affordable price for this particular sustainable, reliable and quality supply of electricity. The main obligation of achieving this goal is an immense amount of unused renewable resources such as solar power. By 2015 it is our goal to achieve $10 \%$ of total energy generation is done by solar system and by 2020 it is our aim to achieve $20 \%$ [2]. Our government is placing priority on developing renewable energy resources to improve energy sector and establish a sustainable energy engine. In government approach Bangladesh Power development board formed the "Directorate of renewable energy and research \& Development in 2010". GOB has taken several steps \& project for achieving the goal. Electricity is the most important source of power for the country's economic activities. The installed capacity in January 2014 [3] is 10289 MW. As a matter of fact we use only three fourth of our power generation around (7716 MW). Only $62 \%$ of our total population has access to electricity with a very limited per capita availability of 321 $\mathrm{kWh}$ per annum [4].

\section{METHODOLOGY}

For calculating the efficiency level of a solar cell we must have to consider several parameters such as I-V curve, Short circuit current (ISC), Open circuit Voltage ( VOC) \& Fill Factor ( FF) [5-9]. All the parameter's characteristics are 
giving the final result to the efficiency. At first we measure the current using the equation -

$$
\mathrm{I}=\mathrm{I}_{\mathrm{L}}-\mathrm{I}_{\mathrm{O}}[\exp (\mathrm{qv} / \mathrm{nKT})-1]
$$

But in equation (1) the -1 term can easily neglected due to exponential term is usually $>1$ except for voltage below $100 \mathrm{mv}$. Now Equation (1) turns to ---

$$
\mathrm{I}=\mathrm{I}_{\mathrm{L}}-\mathrm{I}_{\mathrm{O}}[\exp (\mathrm{qv} / \mathrm{nKT})]
$$

Here, Dark Saturation $\mathrm{I}_{\mathrm{O}}=1 \mathrm{E}^{-10} \mathrm{~A}$,

Light generated current, $\mathrm{I}_{\mathrm{L}}=0.5 \mathrm{~A}$

Ideality Factor, $\mathrm{n}=1$

Temperature, $\mathrm{T}=300 \mathrm{~K}$, Voltage, $\mathrm{V}=0.5 \mathrm{~V}$

$\mathrm{q}$ is charge, $\mathrm{k}$ is Boltzman constant.

By putting this value in equation (2) we obtain, $\quad I=0.4753$ A using light based IV curve calculator.

Using Open circuit voltage equation -

$$
\mathrm{V}_{\mathrm{OC}}=(\mathrm{nKT} / \mathrm{q}) \ln \left(\mathrm{I}_{\mathrm{L}} / \mathrm{I}_{\mathrm{O}}+1\right)
$$

Using the same parameters from equation (2) we have $\mathrm{V}_{\mathrm{OC}}=$ $0.5778 \mathrm{~V}$.

For finding the value of Fill Factor (FF) for efficiency at first we have to find normalized $\mathrm{V}_{\mathrm{OC}}$ using the equation -

$$
\text { Normalized } \mathrm{V}_{\mathrm{OC}}=(\mathrm{q} / \mathrm{nKT}) \mathrm{V}_{\mathrm{OC}} \text { (open circuit) }
$$

From equation (4) we get normalized $\mathrm{V}_{\mathrm{OC}}=22.3304 \mathrm{~V}$. Now we'll use this value to measure Fill Factor ( FF ). [8]

$$
\mathrm{FF}=\left[\mathrm{V}_{\mathrm{oc}}-\left\{\ln \left(\mathrm{V}_{\mathrm{oc}}+0.72\right)\right\}\right] /\left(\mathrm{V}_{\mathrm{oc}}+1\right)
$$

Finally after getting all the values of $\mathrm{FF}, \mathrm{I}_{\mathrm{SC}}, \mathrm{V}_{\mathrm{oc}} \& \mathrm{P}_{\mathrm{in}}$. Then we use them in efficiency equation which is -

$$
\eta=[(\mathrm{VOC} * \mathrm{ISC} * \mathrm{FF}) / \mathrm{Pin}]
$$

\section{PARAMETERS USED FOR FINDING}

\section{EFFICIENCY}

\subsection{Open Circuit Voltage}

$\mathrm{V}_{\mathrm{OC}}$ is the open circuit voltage which is the maximum available voltage from a solar cell occurs at zero current. We can calculate open circuit voltage by using the equation (3) and finally obtained the result $\mathrm{V}_{\mathrm{OC}}=0.578 \mathrm{~V}$.

\subsection{Fill Factor}

The short circuit current $\left(\mathrm{I}_{\mathrm{SC}}\right)$ is the maximum current and open circuit voltage $\left(\mathrm{V}_{\mathrm{OC}}\right)$ is the maximum voltage of a solar cell. Fill factor (FF) is defined as the ratio of maximum power of the product generated by $\mathrm{V}_{\mathrm{OC}} \& \mathrm{I}_{\mathrm{SC}}$ and it is measured in squarness of solar cell and also it reflects the largest rectangle area in IV curves as shown in Fig.1.

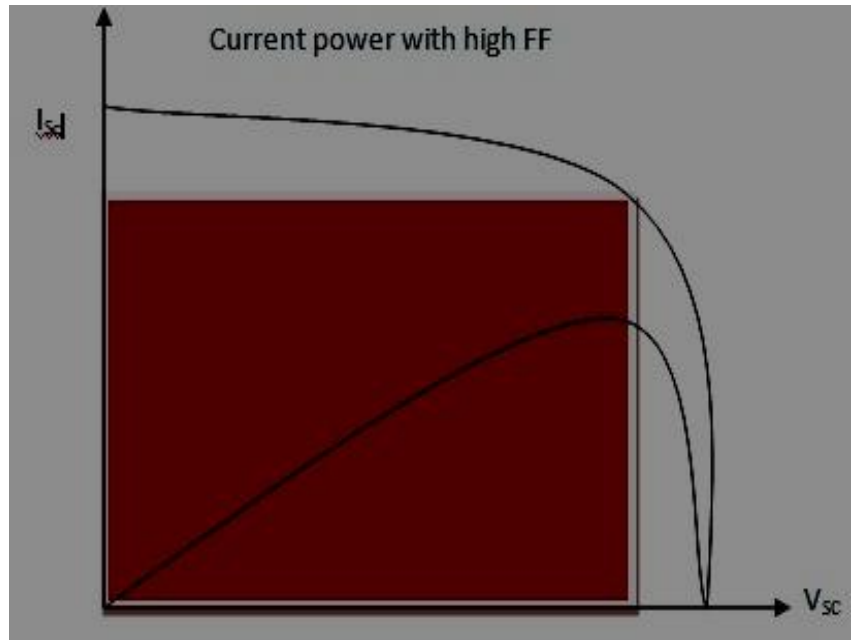

Fig - 1: I-V curve of solar cell indicating Fill Factor

Using equation (5) we obtain the $\mathrm{FF}=0.8226$. And Finally we have to use value of FF, VOC, ISC, \& PIn to the equation (6)and got efficiency, $\eta=17.27 \%$.

\section{CAlculation}

\subsection{For Mono-Crystalline Solar Cell}

For calculation the required equation and respective values are given in methodology part of this paper ( $E^{\mathrm{qn}} 1$ to $\left.E^{\mathrm{qn}} 6\right)$. Calculations of Voltage open Circuit,

$$
\begin{aligned}
\mathrm{V}_{\mathrm{OC}} & =(\mathrm{nKT} / \mathrm{q}) \ln \left(\mathrm{I}_{\mathrm{L}} / \mathrm{I}_{\mathrm{O}}+1\right) \\
& =\left(1 * 300 * 1.38 \mathrm{E}^{-23} / 1.6 \mathrm{E}^{-19}\right) \mathrm{X} \ln \left\{\left(0.5 / 1 \mathrm{E}^{-10}\right)+1\right\} \\
& =0.025875 \times 22.332703 \\
& =0.57785 \text { Volt }
\end{aligned}
$$

But when we go for normalized $\mathrm{V}_{\mathrm{OC}}$ the equation turns into $\mathrm{V}_{\mathrm{OC}}=(\mathrm{q} / \mathrm{nKT}) \mathrm{V}_{\mathrm{OC}}$ (open circuit)

$$
\begin{aligned}
& =(1.6 \mathrm{E}-19 / 1 * 300 * 1.38 \mathrm{E}-23) \times 0.57785 \\
& =22.3304 \text { Volt }
\end{aligned}
$$

Fill factor, $\mathrm{FF}=\left[\mathrm{V}_{\mathrm{oc}}-\left\{\ln \left(\mathrm{V}_{\mathrm{oc}}+0.72\right)\right\}\right] /\left(\mathrm{V}_{\mathrm{oc}}+1\right)$

$$
\begin{aligned}
& =\{22.3304-\ln (22.3304+0.72)\} /(22.3304+1) \\
& =0.8226
\end{aligned}
$$

Finally we can measure the efficiency of a solar cell by using the equation -

$$
\begin{aligned}
\text { Efficiency, } \Pi \quad & =(\text { Voc } * \text { Isc } * \mathrm{FF}) / \mathrm{P}_{\text {in }} \\
& =(0.6 * 3.5 * 0.8226) / 10 \\
& =17.27 \%
\end{aligned}
$$

Here for calculating efficiency we consider input power $1 \mathrm{Kw} / \mathrm{m}^{2}$. ie $100 \mathrm{~mW} / \mathrm{cm} 2$. And for input power $100 \times 100$ $\mathrm{mm}^{2}$ cell $=10 \mathrm{Watt}$.

We will use the same effective equations for calculating Fill Factor ( FF ) for poly crystalline solar cell, then cadmium telluride ( CdTe ) and then ( CIGS ). The only difference we'll go down to up word process. 


\subsection{For Poly-Crystalline Solar Cell}

If we consider open circuit voltage $\left(\mathrm{V}_{\mathrm{OC}}\right)$, and short circuit current $\left(\mathrm{I}_{\mathrm{SC}}\right)$, and input power $\left(\mathrm{P}_{\mathrm{IN}}\right)$ would be same identical value that we use previous equation then from equation no (6) we have -

$$
\begin{array}{ccc} 
& \text { Efficiency, } \Pi=\left(\mathrm{V}_{\mathrm{oc}} * \mathrm{I}_{\mathrm{sc}} * \mathrm{FF}\right) / \mathrm{Pin} \\
\Rightarrow & 0.135=\{(0.6 * 3.5) / 10\} \times \mathrm{FF} \\
\Rightarrow & \mathrm{FF}=0.6428
\end{array}
$$

Here efficiency level of Poly-Crystalline is considered 13.5 $\%$. [10]

\subsection{For CIGS Solar Cell}

$\begin{array}{cl} & \text { Efficiency, } \eta=\left(\mathrm{V}_{\mathrm{oc}} * \mathrm{I}_{\mathrm{sc}} * \mathrm{FF}\right) / \mathrm{P}_{\mathrm{in}} \\ \Rightarrow & 0.11=\{(0.6 * 3.5) / 10\} \times \mathrm{FF} \\ \Rightarrow & \mathrm{FF}=0.5238\end{array}$

Here efficiency level of CIGS is considered $11 \%$. [10]

\subsection{For CdTe Solar Cell}

$$
\begin{array}{llll} 
& \text { Efficiency, } \prod & & \left(\mathrm{V}_{\mathrm{oc}} * \mathrm{I}_{\mathrm{sc}} * \mathrm{FF}\right) / \mathrm{P}_{\text {in }} \\
\Rightarrow & 0.1 & = & (0.6 * 3.5) / 10\} \times \mathrm{FF} \\
\Rightarrow & \mathrm{FF} & =0.47619
\end{array}
$$

$\Rightarrow$

Here efficiency level of CdTe is considered $10 \%$. [10]

\section{RESULT \& DISCUSSION}

From this analytical calculation we have disclosed that the Mono-Crystalline Solar cell has the highest level of efficiency and as well as Fill Factor ( FF ) which is $17.27 \%$ and 0.8226 respectively. On the other hand for Poly Crystalline, CIGS \& CdTe solar cell we have comparatively small value of Fill factor ( $\mathrm{FF}$ ) i.e. $0.6428,0.5238$ \& 0.47619 . It is well proven for a solar cell that the efficiency level is depending upon Fill Factor (FF).

\section{CONCLUSION}

The purpose of this paper is to draw a border line between different types of solar cells used as an alternative power source in an urban area in Bangladesh and successfully we have reached to our goal. Mono crystalline Solar cell has the better performance in course of efficiency which is calculated through Fill factor method (FF). FF is nothing but the squareness of open circuit voltage (VOC) and short circuit current (ISC). Higher value of ' $\mathrm{FF}$ ' indicates that more area of maximum power is generated by the product. In this regard it reveals that for using Solar PV array as a combined power system in a bulk amount we should go for Mono-crystalline Solar cell.

\section{REFERENCES}

[1].http://energyinformative.org/best-solar-panelmonocrystalline-polycrystalline-thin-film/

[2].http://www.bpdb.gov.bd/bpdb/index.php?option=com_c ontent $\&$ view $=$ article $\& i d=26 \&$ Itemid $=24$
[3]. "Key Statistics" Bangladesh Power Development Board. Retrieved 2014-11-03

[4].http://en.wikipedia.org/wiki/Electricity_sector_in_Bangl adesh

[5]. "Hybrid Fuel-cell strategies foe clean power generation" by kaushik Rajashekara, IEEE transaction on industry application, vol-41, No-3, May/June - 2005

[6]. "Renewable energy based small hybrid power system for desalination applications in remote location" by R. Nagaraj IEEE journal 2012.

[7]. Binayak Bhandari, Kyung-Tae Lee, Gil-Yong Lee, Young-Man Cho, Sung-Hoon Ahn, "Optimization of hybrid renewable energy power systems: A review" International Journal of Precision Engineering and Manufacturing-Green Technology, January 2015, Volume 2, Issue 1, pp 99-112.

[8]. Lindholm FA, Fossum JG, Burgess EL. Application of the superposition principle to solar cell analysis. IEEE Transactions on Electron Devices. 1979 ;26:165-171.

[9]. Green MA. Solar cell fil factors General graph and empirical expressions. Solid-State Electronics. $1981 ; 24: 788$ $-789$

[10]. http://energyinformative.org/solar-cell-comparisonchart-mono-polycrystalline-thin-film/

\section{BIOGRAPHIES}

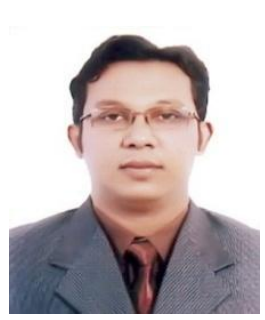

Ruhan Mahmud Shams was born in Dhaka, Bangladesh on $26^{\text {th }}$ October, 1984. Currently he is pursuing his post graduate study under the dept. of Electrical \& Electronic Engineering (EEE) in Dhaka University of Engineering and Technology, Bangladesh. He obtained B.Sc Engineering Degree in Electrical and Electronic Engineering from Stamford University, Bangladesh in 2008. Now he is a faculty member of Atish Dipankar University of Science \& Technology. Since 2014 he is conducting his duty as an Assistant Professor in dept. of EEE. His field of research interest is renewable energy system and also optical fiber communication.

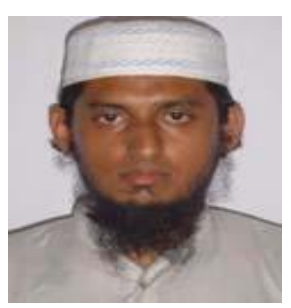

Dr. Md. Sharafat Hossain was born in Khulna, Bangladesh on $4^{\text {th }}$ August, 1978. Currently he is working as an Associate Professor in the Dept. of Electrical \& Electronic Engineering (EEE) in Dhaka University of Engineering and Technology, Bangladesh. He obtained B.Sc and M.Sc Engineering in Electrical and Electronic Engineering from Bangladesh University of Engineering and Technology, Bangladesh in 2004 and 2008 respectively. He obtained P.hD from the University Kebangsaan Malaysia, Malaysia. His field of research interest is Solar Cell, PV systems, renewable energy, nanotechnology and biomedical signal processing. He has more than 40 publications related to his research work. 